\title{
LAATUPIIRIT OPPIVINA TYÖRYHMINÄ
}

Työelämän nopea ja ennakoimaton kehittyminen korostaa henkilöstön jatkuvan oppimisen tarvetta. Tåhän liittyen on alettu pohtia, miten jokapåivåistå tyo̊ympåristo̊å voidaan kehittåå oppimisympåristo̊ksi.

Yhtenä mahdollisuutena on erilaisten kehittåmis- ja itseohjautuvien ryhmien kehittåminen sellaiseksi, ettå niihin osallistuminen tarjoaa ryhmä- ja yksilo̊kohtaisia oppimishaasteita ja oppimismahdollisuuksia. Kyse on kuitenkin vaativasta ja pitkåaikaisesta oppimistapahtumasta, jolle organisaation rakenne, hierarkia ja työnjako voi asettaa monenlaisia reunaehtoja ja rajoitteita. Artikkelissa kåsitellään asiaan liittyviå mahdollisuuksia ja vaikeuksia käytånnön esimerkkien valossa.

\section{Työ oppimisympåristo̊nå}

Elinikäisestä oppimisesta kiinnostuneet tutkijat ovat jo jonkin aikaan vaatineet, että työelämää tulisi kehittää sellaiseen suuntaan, että yksilön mahdollisuudet oppia ja kehittyä kasvaisivat (esimerkiksi Tuomisto 1991,1). Tä. män näkemyksen taustalla on mm. organisaa. tioiden ulkoisten ja sisäisten toimintaympäristöjen yhä nopeampi muuttuminen, mikä pakottaa luomaan uusia henkilöstön kehittämisen menetelmiä. Perinteinen opetukseen perustuva koulutus on käymässä keinona yhä riittämätto̊nämmäksi.

Tavanomainen koulutus etukäteen määriteltyine tavoitteineen ja sisältöineen sopii parhaiten tilanteisiin, joissa muutosnopeus on melko hidasta ja hyvin ennustettavaa. On jopa väitetty, että perinteinen kurssikoulutus toimii yhte. nä suojautumiskeinona ahdistavia muutoksia vastaan ja siten ylläpitää lopultakin vanhaa 164 käytäntöä (Hirschhorn ym. 1989, 199).
Nopeasti muuttuvissa, ennakoimattomissa tilanteissa koeteltujen menettelytapojen opettamisen sijasta painottuu osaamisen nopea ja joustava kehittäminen. Kehittämishankkeet on käynnistettävä ja liikkeelle on lähdettävä ilman, että etukäteen kovin tarkkaan tiedetään, millaisia kohdattavat ongelmat tai niiden ratkaise. misen keinot ovat (kts. esimerkiksi Engeström 1987; Virkkunen 1990).

Toisena keskeisenä perinteisen kouluttamisen ongelmana on se, että uusien tietojen ja taitojen soveltamismahdollisuudet liittyvät työyhteisöjen laatuun. Yksittäinen työntekijä on omaa työtään kehittäessään ja uusia oppeja soveltaessaan varsin paljon sidoksissa lähimpiin työtovereihinsa ja esimieheensä. Esimerkiksi Leymannin $(1989,121)$ mukaan työpaikan infrastruktuuri (sosiaaliset suhteet ja vallankäyttö) vaikuttavat tapahtumiin paljon enemmän kuin koulutusosaston järjestämät kurssit. Työtovereiden ja lähimmän esimiehen on varsin helppo vesittää koulutuksesta saapu- 
neen aktiiviset ja innostuneet ponnistukset, ja kaikki jatkuu niin kuin ennenkin.

Edellä kuvatuista asioista johtuen kouluttamisen sijasta mielenkiinto on suunnattava oppimiseen ja pohdittava, miten oppimista voidaan edistää "luonnollisissa konteksteissa" työyhteisöjen sisällä kiinteässä yhteydessä työhön ja sen kehittämiseen.

Yksittäisen työntekijän työpanos liittyy nykyään yhä monimutkaisempaan kokonaisuuteen. Yksittäisen tuotteen tai palvelun kokonaisuudesta ja laadusta vastaavat useat toisistaan riippuvuussuhteessa olevat työntekijät. Yksittäisen työtekijän työpanoksen kehittäminen ei riitä tuotteen tai palvelun kehittämistyössä. Oppimisyksikkönä ei siten voida pitää yksittäistä työntekijää, vaan sitä ryhmää, joka aikaansaa tuotteen tai palvelun. Siksi oppimisen ja kehittämistyön tulee tapahtua koko ryhmän toimesta ja siten, että kaikki ryhmän jäsenet voivat aktiivisesti osallistua kehittämiseen. Tällainen aktiivinen kehittämistyö sekä edellyttää uuden oppimista että aikaansaa sitä.

Edelleen voidaan väittää, että yksittäisen ryhmänkään oppiminen ei ole riittävää. Tarvitaan eri ryhmien kehittämistyön yhteensovittavaa, kokonaisvaltaista ohjaamista ja suuntaamista koko organisaation kokonaisjärjestelmän kehittämiseksi. Ryhmäoppimisen haaste laajenee (Sarala 1989) ja kysymys voidaan asettaa seuraavasti: miten saamme aikaan työryhmien osaamisen nopean ja joustavan kehittämisen niin, että se niveltyy koko organisaation muodostaman toimintajärjestelmän kehittämiseen ja tukee sitä?

Nämä haasteet ovat johtaneet siihen, että yhä enemmän on alettu pohtia ja kokeilla työssä oppimisen mahdollisuuksia. Esimerkiksi Cottrell (1976) käyttää tässä yhteydessä käsitettä "yhteisölliset taidot" (community competence). Nämä taidot ovat nykyisessä työyhteisössä yhtä tärkeitä kuin tekniset taidot ja ne on saavutettavissa vain osallistumisen ja ryhmätoiminnan avulla.

\section{Kokeiluja ja tutkimuksia työryhmisså oppimisesta}

Seuraavat piirteet ovat usein yhteisiä ja tyy. pillisiä kirjallisuudessa ja tutkimusraporteissa esitetyille hankkeille, jotka koskevat oppimista ryhmissä.

Työssä oppimisen edellytykset on luotu siten, että työntekijäryhmille on annettu mahdollisuus oman työnsä kehittämiseen. Kehittä- minen on monasti suuntautunut esimerkiksi työturvallisuuden ja työviihtyvyyden parantamiseen työympäristöä muuntamalla (esimerkiksi Löfberg 1989). Osallistumisen on osoitettu edistävän myös työntekijöiden hyvinvointia ja terveyttä (esimerkiksi Van Bainum 1985).

Kehittämistyö on tehty kehittämisryhmissä siten, että työntekijät ovat pohtineet oman työnsä parantamiskeinoja sekä käytännön kokeilujen kautta etsineet sopivia ja toimivia ratkaisuja. Esimerkkinä tällaisista kokeiluista voidaan mainita Löfbergin raportoimat hankkeet. Ryhmätoiminnan yhteydessä oppiminen ta. pahtuu erityisesti ryhmässä käytävän pohdin. nan ja keskustelun aikana ja ansiosta (Leyman 1989, 132 ; Löfberg 1989, 149). Hankkeiden toteuttamisen yhteydessä on korostettu todellisen osallistumismahdollisuuden tarjoamista työntekijälle.

Edellä kuvatun tapaisiin kehittämishankkeisiin liittyy mielestäni seuraavia rajoitteita ja ongelmia:

1. Kehittäminen on usein etukäteen rajattu liikaa esimerkiksi työsuojelukysymyksiin. Työturvallisuus ja viihtyvyys ovat tärkeitä, mutta keskittymällä vain niihin ei oteta riittävästi huomioon toiminnan laadun kokonaisvaltaista kehittämistä. Tämä edellyttää huomion kiinnittä. mistä laajempiin työn suunnittelu- ja yhteistyö. kysymyksiin.

2. Hankkeiden taustalla oleva oppimisnäkemys painottaa liian yksipuolisesti arkikoke. muksen merkitystä ja riittävyyttä. Oppimisen katsotaan tapahtuvan itsestään ja lähes huomaamatta toiminnan ohessa. Näin oppimista ei voida riittävästi kehittää tietoisena ja myös itsessään kehittyvänä toimintana. Perinteisen koulutuksen keinojen yksipuolinen hylkääminen ja korvaaminen kokemusperäisellä työssä oppimisella jättää käyttämättä monia mahdollisuuksia. Ongelman jäsentämisen ja tiedon hankinnan taitoja voidaan opettaa perinteisillä. kin koulutusmenetelmillä. Kehittämistyössä ilmeneviin tiedontarpeisiin voidaan myös osaltaan vastata koulutuksen keinoin.

Edelleen tulisi korostaa riittävän laajan yleissivistyksen ja tietouden merkitystä luovalle ongelmanratkaisulle. Kehittämisideat eivät synny tyhjästä, vaan ovat monasti yhteydessä henkilöiden laajempaan elämäntaustaan.

3. Kehittämisryhmien käytössä ei ole riittävästi hyödynnetty esimerkiksi laatupiiritoiminnas. 
sa jo parin vuosikymmenen ajalta kertynyttä kokemusta. Näitä kokemuksia tarkastellaan seuraavassa.

\section{Laatupiiritoiminta ryhmåsså tapahtuvan oppimisen yhtenå lähtökohtana}

Laatupiiritoiminta alkoi maassamme 1970. luvun lopulla ja sen painopiste sijoittui 1980 . luvulle. Sillä tarkoitetaan oman työn kehittämistä pienissä 4-8 henkilön ryhmissä. Laatupiirit kokoontuvat säännöllisesti noin kolmen vuoden välein. Kehittäminen tapahtuu etukäteen opetettujen menetelmien avulla. Toiminnassa painotetaan konkreettisten parannusten aikaansaamista. Suomessa perinteisten laatupiirien määrä on vähentynyt 1990-luvulle siirryttäessä, mutta toisaalta toiminta on saanut uusia muotoja ja nimityksiä.

Kansainvälisesti tarkasteltuna maassamme toteutettujen laatupiirien perusongelmia on ollut ylläpitää jatkuvuutta. Virheellisesti on väitetty, että tämä liittyy meillä laatupiiritoiminnan japanilaiseen alkuperään ja siihen liittyvään kulttuurien erilaisuuteen. Alkuperäiset toiminta-ajatukset kehitettiin aikoinaan Yhdysvalloissa. Suomessa jatkuvuusongelmat liittyvät nimenomaan organisaatioiden byrokraattiseen toimintatapaan ja liian pitkälle eriytettyyn tayloristiseen työnjakoon, joka vaikeuttaa toiminnan kehittämistä tuote-, palvelu- ja asiakaskeskeisesti. (Taylorismin nimitys on peräisin Fredrik Taylor -nimisestä henkilöstä, joka loi massateollisuuden perustana olleen töiden organisointitavan. Työn suunnittelu ja toteutus erotettiin toisistaan ja työ jaettiin pieniin osavaiheisiin. Aikanaan menettelytapa mahdollisti kouluttamattoman työvoiman käytön ja mahdollisti suurten sarjojen halvan valmistamisen. Nykyään toiminnan ehdot ja olosuhteet sekä henkilöstön koulutustaso ovat täysin muuttuneet. Tästä huolimatta tätä työn suunnitteluperiaatetta noudatetaan sovellettuna edelleen monissa organisaatioissa.) Japanissa ja Yhdysvalloissa laatupiiritoiminta kuuluu monien hyvin menestyneiden organisaatioiden päivittäisiin toimintarutiineihin (Lillrank 1988).

Laatupiiritoiminnan hyvinä puolina voidaan mielestäni pitää seuraavia asioita:

Menetelmä ja sen käyttöön johdattava koulutus ovat hioutuneet vuosien varrella ja toimintaa on tutkittu melko paljon eri maissa. Laatupiireihin ohjaavilla peruskursseilla kiinnitetään erityistä huomiota pienryhmätoimin166 taan ja järjestelmälliseen ongelmanratkaisuun, jota varten opetetaan mm. syy-seuraus-analyysien tekoa. Ilman tällaista koulutusta ryhmät yleensä valitsevat kehittämistoimenpiteet melko umpimähkään ja tekevät ongelma-analyysin liian pinnallisesti (kts. myös Sköld 1978, 303).

Tekijällä on ollut mahdollisuus tutustua tarkemmin esimerkiksi Asko Oy:n laatupiireihin 1980-luvun alussa sekä Helsingin kaupungin rakennusvirastossa toteutettuun laatupiiritoimintaan (Sarala 1986 ja 1990). Asko Oy:ssä tutkittiin mm. laatupiirien kustannus-hyötysuhdetta. Tällöin todettiin, että näin aikaansaadut kustannussäästöt olivat seurantavuoden 1984 aikana yhtymään kuuluvassa valimossa noin 1784500 markkaa ja huonekalutehtaalla noin 500000 markkaa. Hyöty oli moninkertainen verrattuna kustannuksiin. Helsingin kaupungin rakennusviraston laatupiiritoiminnan tuloksia selostetaan hieman yksityiskohtaisemmin seuraavassa.

Laatupiiritoiminnan käyttöönottoa alettiin pohtia Helsingin kaupungin rakennusvirastossa syksyllä 1983. Vuodesta 1984 lähtien on toimivia piirejä ollut yhteensä 21 kappaletta. Osa on jo lopettanut toimintansa mm. henkilömuutosten takia. Samaan aikaan on synty. nyt uusia piirejä. Tällä hetkellä toiminnassa on 14 piiriä. Näiden toimivien ryhmien lisäksi neljä piiriä on aloittamassa toimintaansa. Eniten kokouksia oli pitänyt katuosaston laatupiiri, Mertapiiri, yhteensä noin 126 kokousta. Koko viraston laatupiirien kokousten määrä on kuuden vuoden ajalta noin $600 \mathrm{kpl}$ ja niissä on käsitelty yli 200 ongelma-asiaa, joihin liittyvät parannusehdotukset on toteutettu.

Yksittäisistä parannuksista kertyvä taloudellinen tuotto on laskettu ja arvioitu lähes miljoonaksi markaksi viimeisen neljän vuoden ajalta. Muina ei laskettavissa olevina tuottoina on voitu samalta ajalta kirjata monet työympäristöä, tuotteen (esimerkiksi kunnossapidon) laatua, varastojärjestelyjä, työturvallisuutta, työviihtyvyyttä jne. koskevat parannukset.

Monet pitävät laatupiiritoiminnan ns. "pehmeitä" tuloksia paljon tärkeämpinä kuin markoissa laskettavia kustannussäästöjä. Pehmeillä tuloksilla tarkoitetaan parannuksia työpaikan ilmapiirissä ja työtekijöiden motivaatiossa. Laatupiiritoiminta voi parantaa työntekijöiden työmotivaatiota antamalla vaikutusmahdollisuuksia oman työn kehittämiseen ja sitä kautta lisäämällä työn kiinnostavuutta sekä haasteellisuutta. Tämä edellyttää kuitenkin, että itse ryhmässä toimiminen koetaan kiinnostavana ja että se sujuu riittävän hyvin. Toisaalta 
ryhmän on myös aikaansaatava todellisia tuloksia. Muutoin yhdessäolo voi kyllä parantaa yhteishenkeä, mutta itse työn kannalta toiminta on lähinnä viihteellistä.

Laatupiiritoiminnan aikaansaamiin kustannussäästöihin voidaan suhtautua monella tavalla. Jonkun mielestä ne voivat olla suuria, toinen taas voi vähätellä rahasummia ja verrata niitä esimerkiksi koko viraston vuosibudjettiin. Arvioita tehtäessä on syytä muistaa, että on olemassa varsin vähän sellaisia organisaation kehittämishankkeita, joiden tuloksia voidaan osoittaa markoissa. Mikä on esimerkiksi valtionhallinnossa viime vuosikymmenellä ponnekkaasti toteutetun tavoitejohtamisen aikaansaama markkatulos? Tai mikä on nyt muodissa olevan tulosjohtamisen aikaansaama markkatulos?

Vaikka tulosta ei voida tarkasti kiteyttää markoiksi, ei tämän perusteella kuitenkaan yleensä vedetä sitä johtopäätöstä, että organisaation kehittäminen ei kannata? Esimerkiksi laatupiiritoiminnan "kotimaassa" Japanissa pidetään laatupiirin muita tuloksia tärkeämpänä kuin rahassa mitattavia tuloksia (Lillrank 1988).

Laatupiirien menestys ei kaikissa organisaatioissa ole ollut yhtä hyvä kuin edellä on kuvattu. Monin paikoin toiminta on tukahtunut työnjohdon vastustukseen tai sammunut sopivien kehittämiskohteiden puutteeseen. Monissa länsimaissa laatupiiritoiminta on ollut lopultakin lähinnä muoti-ilmiö ja laatupiirien määrä on sekä Suomessa että monissa Euroopan maissa nopeasti vähenemässä. Toimintaa voidaan myös aiheellisesti kritisoida siitä, että sen avulla aikaansaadaan vain melko vähäisiä ja rajoittuneita "pintaparannuksia". Rajaamalla piirien toimivaltaa voi työnjohto ja keskijohto estää suuremmat uudistukset ja pitää töiden organisointitavan ja töiden sisällön ennallaan. Näin säilytetään perinteinen johtamistyyli ja vallankäyttö.

Edellä kuvatuista rajoitteista huolimatta laatupiirejä ja niiden toiminnan yhteydessä hankittuja kokemuksia voidaan käyttää hyväksi työryhmien toimintaa kehitettäessä.

\section{Kohti oppivia työryhmiä}

Laatupiiritoimintaa voidaan mielestäni kehittää kolmella eri käyttöalueella, jotka ovat:

- perinteisen laatupiiritoiminnan kehittäminen oppiviksi työryhmiksi,

- laatupiirien toimintamenetelmien sovelta- minen itseohjautuvien työryhmien puitteissa ja

- yhteistyö- ja toimintaverkkojen aikaansaanti ja ylläpito laatupiiritoiminnan menetelmiä hyödyntämällä.

Tarkastelen näitä kehittämistapoja seuraavassa yksitellen.

\subsection{Perinteisen laatupiirien kehittäminen oppiviksi työryhmiksi}

Perinteistä laatupiiritoimintaa voidaan kehittää erityisesti kouluttamalla ryhmiä tietotaidon hankintaan ja korostamalla tietoista oppimista ja elämänhallinnan kehittymistä laatupiiritoiminnan keskeisinä tavoitteina. Helsingin kaupungin rakennusviraston laatupiiritoiminnassa tämä on tarkoittanut seuraavia käytännön toimenpiteitä.

Laatupiirien peruskursseilla on yhtenä keskeisenä aiheena käsitelty teemaa Mitä laatupiiritoiminnassa voi oppia? Jakson aikana on kerrottu jo toimivien laatupiirien toiminnan tuloksista, oppimiskokemuksista ja ryhmien käyttämistä tietotaidon hankintatavoista. Tällä tavalla ryhmiä on suunnattu kiinnittämään huomiota tietoiseen oppimiseen ja rohkaistu niitä itsenäiseen tiedonhankintaan sekä yhteydenottoihin laatupiirien ulkopuolisiin asiantuntijatahoihin.

Laatupiirien toimintaa ja sen tuloksia on seurattu ja siitä on annettu palautetta. Olemme esimerkiksi nauhoittaneet yhden ryhmän (laatupiiri "Torstai") kokoukset vuoden ajalta ja analysoineet nauhat ongelmanratkaisun tehokkuuden ja toiminnan sujumisen kannalta. Tästä aineistosta on tehty kaksi aikuiskoulutuksen syventävien opintojen tutkielmaa (Jälkö 1990 ja Winter 1991). Koko rakennusviraston laatupiiritoimintaa ja sen tuloksia on tutkittu sekä yleisesti että ryhmäkohtaisesti (Sarala 1990). Näistä tutkimuksista tehdyt tiivistelmät on jaettu rakennusviraston avainhenkilöille ja laatupiireille. Lisäksi ajankohtaistuloksia on raportoitu viraston henkilöstölehdissä. Menestyneille piireille on annettu rahapalkintoja.

Lähemmän tutkimuksen kohteena olleesta laatupiiri "Torstaista" saatiin sen toiminnan tutkimisen yhteydessä mielenkiintoisia tuloksia. Piirin toiminnan kohteena on katujen puhtaanapito. Piiri totesi analysoidessaan oman työtoimintansa ongelmia, että puhtaanapitoa hidastavat suuresti kaikenlaiset esteet ja raken- 
teet kuten esimerkiksi hankalasti sijoitetut sähkökaapit, kaiteet, bussikatokset, liikenne. merkit jne. Ryhmä otti kehittämistyön kohteeksi puhtaanapitoa. haittaavien esteiden poistamisen tai vähentämisen. Ryhmän toiminnan etenemisen vaiheita ja niiden merkitystä oppimisen kannalta selostetaan seuraa. vassa:

1. Piiri aloitti toimintansa kartoittamalla puhtaanapidon haitat syy- ja seurausanalyysin avulla. Analyysi kiteytettiin syy-seurauskaavioksi. Oppimisen kannalta kyse on oman työn tutkimisesta ja jåsentämisestä, jota kognitiivisen oppimisnäkemyksen mukaan kutsutaan oman työn orientaatioperustan hahmottamisesta (kts. esimerkiksi Engeström 1984).

2. Tämän tehtyään ryhmä tutustui säädöksiin ja määräyksiin, jotka koskevat kadun ja teiden rakenteita ja niiden sijoittamista. Oppimisen kannalta kyseessä on tiedon hankinta omalle työlle rajoituksia asettavista säädöksistä ja sää. dösten suhteuttamisesta omaan toimintaym. päristöön.

3. Edellisen vaiheen tuloksena ryhmä totesi, että monessa tapauksessa voimassa olevat säädökset ja määräykset mahdollistavat liikennemerkkien, sähkökaappien jne. nykyistä paremman sijoittamisen. Katujen suunnittelussa voidaan siis nykyistä paremmin ottaa myös puhtaanapidon vaatimukset huomioon. Tämä edellyttää kuitenkin, että katujen suunnittelijat saadaan tiedostamaan asia entistä paremmin. Suunnittelukäytännön kehittäminen edellyttää yhteistyön syntymistä katujen suunnittelun ja katujen puhtaanapidon välille. Oppimisen kannalta kyse on siitä, että ryhmä joutuu suhteuttamaan oman toimintajärjestelmänsä laa. jempaan organisaation toimintajärjestelmään. Samalla viriää tarve murtaa tayloristinen työn organisointiperiaate, jossa työn suunnittelu ja toteuttaminen on eriytetty toisistaan sekä halu aikaansaada yhteistyötå pitkälle eriytetyn byrokraattisen organisaation eri osien vålille.

4. Tähän asti edettyään ryhmä pohti muutoksen aikaansaantikeinoja ja totesi, että byrokraattisessa organisaatiossa suunnittelijat voi saada yhteistyöhön työntekijöiden kanssa vain vapaaehtoisuuden pohjalta. Piiri päätti järjestää asiaa koskevan tiedotustilaisuuden, johon kutsuttiin suunnittelijat ja rakennusviraston avainhenkilöitä. Asiaa päätettiin havainnollistaa diasarjan avulla, jossa esitettiin tyyppitapauksia puhtaanapidon kannalta hankalista kohteista. Näitä kohteita kartoitettiin suunnit- telemalla lomake, jonka avulla aurojen ja tiekarhujen kuljettajat voivat omalla alueellaan kartoittaa puhtaanapidon kannalta hankalat paikat ja kirjata niitä koskevat tiedot lomakkeelle. Täytetyt lomakkeet kerättiin ja analysoitiin piirin toimesta. Ryhmä valitsi kuvauskohteet ja diasarja kirjallisine selostuksineen valmistettiin. Oppimisen kannalta kyse on ongelmallisten alueiden kartoituksesta ja analyysistå yhteistyössä ryhmän ulkopuolisten työntekijöiden kanssa sekä parannuksen aikaansaamista koskevan suunnitelman laadinnasta ja havaintomateriaalin suunnitte. lusta sekä valmistamisesta.

5. Ryhmä valmisteli tiedotustilaisuuden yhdessä virastossa laatupiiritoiminnasta vastaavan henkilön kanssa. Tilaisuuteen kutsuttiin rakennusviraston omien suunnittelijoiden lisäksi myös energialaitoksen suunnittelijoita, jotka vastaavat sähkökaappien sijoittamisesta. Oppimisen kannalta kyse on sen oivaltamises. ta, että omassa organisaatiossa aikaansaadun yhteistyön lisäksi tarvitaan myös eri organisaatioiden vålistä yhteistyo̊tå.

6. Tilaisuus toteutettiin suunnitelmien mukaisesti. Tilaisuuden seurauksena jotkut piirin alueella sijaitsevat kohteet korjattiin helpom. min puhdistettaviksi siirtämällä esimerkiksi lii. kennemerkkejä. Laajempaa suunnittelijoiden ja työntekijöiden välistä yhteistyötä ei vielä ole saatu aikaan. Rakennusviraston johto on lähtenyt tukemaan yhteistyön syntymistä ja näissä merkeissä laatupiiri "Torstai" järjesti 12.6. 1991 toimintansa tulosten esittämistilaisuu. den, jonne oli kutsuttu katujen suunnittelusta vastaavat henkilöt. Ryhmä oli tehnyt tilaisuutta varten huolellista valmistelutyötä luetteloimalla ja analysoimalla puhtaanapidon haittakohteet. Haittojen maininnan lisäksi ryhmä tekee korjausehdotuksen. Monisteessa on myös karttaliitteet, joihin haittakohdat on merkitty. Oppimisen kannalta kyse on siitä, että ryhmä näkee toimintansa johtavan tuloksiin, mutta samalla saa kokea, miten vaikeaa on murtaa tayloristiselle työnjaolle ominaista tapaa eriyttää suunnittelu ja toiminta toisistaan.

Edellä selostetun hankkeen jälkeen laatupiiri "Torstai" on kehitellyt yhteistyömuotoja kadun puhtaanapitäjien ja paikallisten asukkaiden välillä. Ryhmä on lähestynyt niitä asukkaita monisteen avulla, joiden kanssa tarvitaan yhteistyötä kunnossapidon ongelmien ratkaisemiseksi. Oppimisen kannalta kyse on asiakaskeskeisyyden korostumisesta oman toiminnan suunnittelussa ja toteuttamisessa. Mielenkiintoista on myös, että ryhmä on val. 
mistanut työnopastusvihon uusia työntekijöitä varten. Vihon laadinta sai alkunsa ryhmän oivaltaessa, että puhtaanapidon nopeus kytkeytyy myös siihen, miten joustavasti ja nopeasti työntekijät hoitavat tehtävänsä. Vihkoon on kerätty työn sujuvuutta lisääviä ohjeita ja tietoja, joiden avulla ryhmä pyrkii oma-aloitteisesti ja aktiivisesti kouluttamaan ja opastamaan uusia työntekijöitä.

Kuten edellä olevasta tarkastelusta ilmenee, työtä voidaan tarkastella opetussuunnitelmana ja kysyä millaisia asioita työ opettaa tekijöil. leen työntekijöiden omasta työstä ja koko organisaatiosta. (Työn tarkastelu opetussuunnitelmana tarkoittaa mm. sitä, että työtä pyritään muotoilemaan niin, että se sisältää uuden tie. don tuottamista ja luovaa ongelmanratkaisua (Löfberg 1989,1). Tätä laajempi tarkastelukul. ma analysoi kaikkea työhön liittyvää, kuten töiden sisältöä. johtamista, sosiaalista työyhteisöä jne. oppimisvaikutusten kannalta.)

Oppimisen tulokset voivat niiden laadusta riippuen joko rohkaista ryhmää jatkamaan kehittämistyötä tai sitten tukahduttaa kehittämis. halun. Työ voi siis myös opettaa tekijänsä avuttomaksi ja voimattomaksi (ks. Kornbluch Greene 1989, 259)

\subsection{Menetelmien soveltaminen itseohjautuvien työryhmien kehittåmistyősså}

Laatupiirien työskentelytapa liittyy itseohjautuvien työryhmien työhön. Itseohjautuvien työryhmien käyttö on vähitellen yleistymässä myös Suomessa. Tällainen työskentelytapa edellyttää työntekijöiltä aiempaa suurempaa osallistumista oman työn suunnitteluun. Valitettavasti meillä ja muissa Pohjoismaissa itseohjautuvia ryhmiä käytetään lähinnä työn rikastuttamistarkoitukseen, jolloin toiminnan jatkuva kehittäminen on edelleen pääsääntöisesti jonkun ryhmän ulkopuolisen henkilön vastuulla. Vertailukohtana on japanilainen tapa toimia itseohjautuvissa työryhmissä. Heillä toiminnan jatkuva kehittäminen on itseohjautuvuuden keskeinen osa ja se toteutetaan laatupiiritoiminnan avulla. Työn tuottavuusluvut puhuvat puolestaan ja osoittavat, että japanilainen soveltamistapa on myös Euroopassa johtanut tehokkaampaan lopputulokseen (Toikka 1991).

Laatupiiritoiminnan työkaluilla olisi selvästi kysyntää, jos japanilaistyyppinen, myös oman toiminnan kehittämistyön mukaan ottava toimintatapa, yleistyisi itseohjautuvissa työryhmissä. Eräänä mahdollisuutena olisi opettaa työntekijöille työn suunnittelumenetelmiä ja samalla laatupiiritoiminnan työkaluja. Esimerkiksi vakuutusyhtiö Kansassa on töitä organisoitu uudelleen niin, että itseohjautuvat työryhmät ovat voineet suunnitella oman työnsä organisaation ja toteuttamistavat. Tällöin on voitu todeta, että työn suunnittelumenetel. mien opettaminen auttaa itseohjautuvia työryhmiä niiden suunnittelutehtävässä.

\subsection{Yhteistyo̊- ja toiminta- verkkojen aikaansaanti ja yllåpito}

Kolmantena käyttötapana on, että laatupiirit nähdään pääasiassa kommunikaatio- ja yhteysverkoston luomisen ja ylläpidon välineenä. Tällöin tunnusomaista on se, että piirin jäsenet sijaitsevat eri puolilla organisaatiota tai koko. naan eri organisaatioissa. Samoin jäsenet voivat olla eri organisaatiotasoilta: työntekijöitä, suunnittelijoita, johtoa jne.

Ryhmän koostumus määräytyy kehitettävän toiminnan, palvelun tai tuotteen kautta. Ryhmien koostumus on vain osittain pysyvä ja tunnusomaista on, että osa jäsenistä vaihtuu kehitystehtävien mukaisesti. Tämä on laatupiiritoiminnan kehittynein ja vaativin muoto.

Organisaatioiden sisäinen valtahierarkia ja kilpailu reviireistä ei aina tue organisaatioiden välistä yhteistyötä. Paljolti jää piiriläisten oman motivaation ja sen varaan, löydetäänkö haastavia ja motivoivia kehittämistehtäviä. Tällaista käyttötapaa kokeiltiin Oulun yliopiston Kajaanin täydennyskoulutusyksikössä. Siellä järjes. tettiin laatupiirikoulutusta eri maatalousorganisaatioiden maatalousneuvojille ja kouluttajille. Tekijä oli tällä kurssilla kouluttajana ja konsulttina. Kajaanin laatupiirikoulutuksen perusteel. la syntyneet laatupiirit pyrkivät muodostamaan toimivan yhteistyö- ja kommunikaatioverkon eri maatalousorganisaatioiden välille. Toiminta on lähtenyt liikkeelle hyvin, mutta jatkuvaan toimintaan pääsy edellyttää paljon yhteisiä ponnisteluja. Hankkeesta on kerätty seurantatietoa, jotta saatuja kokemuksia voidaan jatkossa hyödyntää (Sarala 1991). Eräs kurssin aikana perustetusta ryhmästä on lähettänyt aikaansaannoksiaan (mm. asiakkaan näkökulmasta tehty eri neuvontaorganisaatioiden järjestämän koulutuksen yhteisesite). 


\section{Yhteenveto laatupiireistä oppimisen välineinä}

Olen edellä pyrkinyt osoittamaan miten laatupiireissä kokeiltuja ja kehitettyjä menetelmiä voidaan hyödyntää sellaisten itseohjautuvien työryhmien työssä, jotka osaltaan tähtäävät työtoiminnan kehittämiseen. Keskeistä on nähdä, että perinteisestä ylhäältä johdetusta työskentelytavasta siirtyminen itseohjautuvampaan toimintaan on pitkäjänteisyyttä, ohjausta ja organisaation tukea edellyttävä opetus- ja oppimistapahtuma. Tämän prosessin keskeiset piirteet kiteytetään seuraaviksi ydinkohdiksi:

- Osaamisen kehittäminen ja oppiminen tapahtuu yksilöissä, mutta sen tulee tapahtua ryhmän puitteissa ja luonnollisissa työyhteisöissä.

- Oppimisen lähtökohtana tulee olla kehitettävä toiminta ja siitä nousevat haasteet - ei jonkun ulkopuolisen suunnittelema kurssi.

- Perinteistäkin koulutusta tarvitaan lähin. nä kahdessa asiassa. Henkilöstölle on opetettava työn kehittämisen ja tiedon hankinnan välineet. Uutta tietoa painottavan sisällöllisen koulutuksen vuoro on vasta sitten, kun sen avulla voidaan luontevasti ja ajankohtaisesti vastata kehittämistyössä esiinnousseisiin haasteihin.

- Myönteiset oppimiseen ja kehittämistyöhön liittyvät kokemukset voivat parhaimmillaan innostaa ryhmiä laajempaankin työorganisaation kehittämiseen ja määrätietoiseen jatko-opiskeluun. Asko Oy:ssä suoritetun laajan henkilöstökoulutushankkeen yhtenä myönteisenä sivutuotteena oli se, että jotkut kursseille osallistuneet innostuivat aloittamaan ammatilliset jatko-opinnot (Sarala 1986). Tällaisen aktiivisen elämänhallinnan tavoittelua voidaankin pitää yhtenä itseohjautuvan ryhmätyön oheistavoitteena. Näihin laajempiin oppimisvaikutuksiin on kiinnitetty huomiota saksalaisessa työpsykologiassa jo 1980 luvun alkupuolella (kts. esimerkiksi Volpert ym. 1983 ; Duel ym. 1985).

Hiukan laajemmasta näkökulmasta käsin edellä selostetut kehittämishankkeet ovat kuitenkin vain yhdenlaisia esimerkkejä siitä miten työelämää yritetään kehittää suotuisaksi oppimisympäristöksi. Kriittisesti tarkasteltuna voidaan sanoa tämänsuuntaisen kehityksen ja sitä vauhdittavan kehittämistyön olevan vielä hy- varsin vähän aikaan ja kehittämishankkeiden jatkuvuuskin on yleensä epävarmaa.

Monet organisaatioiden rakenteeseen, valtaan ja työnjakoon liittyvät asiat tulevat vastakin jarruttamaan edellä kuvattua kehitystä ja sammuttamaan lupaavastikin alkaneita hankkeita. Onnistuneiksi raportoidut kehittämishankkeetkin edellyttävät usein jokapäiväistä työelämää ajatellen epärealistisen suuria ja pitkäaikaisia ohjaus- ja tukitoimia.

Meidän työelämän kehittämishankkeissa mukana olevien tutkijoiden on joskus vaikea muistaa, että kriittistä tarkastelua ja reflektointia tulee riittävästi kohdistaa myös niihin kehityshankkeisiin, joissa itse olemme mukana aktiivisina ja osallisina tutkijoina.

\section{LÄHTEET}

Cottrell, L. Jr. 1976. The competent community. In Kaplan, B.H. Wilson, R.N. and Leighton A: H. (eds. ), Further Explorations in Social Psychiatry. New York: Basic books.

Duell, W and Frei, F. 1985. Handbook for Qualifying Work Organization. Zurich: Eidgenoessiche Technische Hochschule, Lehrstuhl für Arbeits - und Organisationspsychologie.

Emery, M. 1982. Searching. Toronto QWL Centre.

Engeström, Y. 1984. Orientointi opetuksessa. Valtion koulutuskeskus. Julkaisusarja B nro 29, 1984. Helsinki: Valtion painatuskeskus.

Engeström, Y. 1987. Learning by expanding. Helsinki: Orienta-Konsultit Oy.

Hirschhorn, L., Gilmore, T. and Newell, T. 1989. Training and learning in a post-industrial world. Teoksessa Leyman H. ja Kornbluh, H. 1989. Socialization and learning at work.

Jälkö, A. 1990. Laatupiirin ongelmanratkaisuprosessi. Aikuiskasvatuksen syventävien opintojen tutkielma sl. 1990 . Helsingin yliopiston kasvatustieteen laitos. Aikuiskasvatuksen syventävien opintojen tutkielma.

Leymann, H. and Kornbluh H. 1989. Socialization and learning at work. Gower Publishing Group.Hampshire, England.

Lillrank, P. 1988. Organizations for continuous improvement.

Löfberg A. 1989. Learning and educational intervention from constructive point of view: the case of workplace learning. Teoksessa Leyman, H. ja Kornbluh, H. 1989. Socialization and learning at work, 137-158. 
Sarala, U. 1986. Henkilöstökoulutuksen mahdollisuudet teollisuusyrityksen kehittämisessä. Tapausesimerkkinä Asko-koulutusprojekti. Helsingin yliopiston kasvatustieteen laitos. Tutkimuksia 109.

Sarala, U. 1988. Kohti oppivaa organisaatiota -aikuiskoulutus organisaatiossa. Helsingin yliopisto Lahden tutkimus- ja koulutuskeskus.

Sarala, U. 1990. Laatupiiritoiminta Helsingin kaupungin rakennusviraston kehittämiskeinona. Helsinki. Julkaisematon kehittämishankkeen seurantaraportti.

Sarala, U. 1991. Kajaanin täydennyskoulutusyksikön järjestämän laatupiirikoulutuksen arviointia. Julkaisematon kurssiarviointi.
Sköld, M. et al. 1978, Arbete i gatumiljö. Stockholm: Arbetarskyddsfonden.

Toikka, K. 1991. Ryhmätyö auton kokoonpanossa: humanisointia vai hyperfordismia? TKK:n työpsykologian laboratoriossa järjestetyssä työpsykologian forumissa 25.4.1991 jaettu moniste.

Tuomisto, J. 1991. The development of trade union education and new challenges - a Finnish perspective. Kongressiesitelmä: An International Conference on Developing Relationship Between Trade Unions and Research Organizations. 15-18 July 1991. Oxford. 


\section{AIKUISKASVATUS}

The Finnish Journal of Adult Education

Vol. 11, 3/91

ISSN 0358-6197

Summary

Sarala Urpo 1991. Laatupiirit oppivina työryhminä.

- Työelämän nopea muuttuminen korostaa henkilöstön jatkuvan oppimisen tarvetta. Erillisen kouluttamisen sijasta ja rinnalla pohditaan oppimista työyhteisön sisällä kiinteässä yhteydessä työhön ja sen kehittämiseen. Japanissa ja Yhdysvalloissa laatupiiritoiminta on kuulunut monen hyvin menestyvän organisaation päivittäisiin toimintarutiineihin. Artikkelissa tarkastellaan laatupiiritoimintaa työyhteisössä, sen etuja ja aikaansaannoksia, rajoitteita ja on-
Sarala Urpo 1991. Quality circles as learner work groups.

- The rapid changes taking place in the work life place increasing emphasis on the need for continuous learning on the part of personnel. In place of and alongside separately arranged training there are plans for arranging and developing learning within the work community in direct contact with work. Quality circles are part of the daily routine in many successful companies in Japan and the United States. The article examines the quality circle as an 
gelmia sekä laatupiiriä oppimisen välineenä suomalaisten kokemusten ja kokeilujen valossa. Aikuiskasvatus 11,3. aspect of the work community, its advantages and what has been achieved through it, its limitations and problems, and lastly quality circles as a learning aid in the light of Finnish experiences and experiments.

Aikuiskasvatus 11,3. 